\title{
Pengenalan Suara Paru-Paru dengan MFCC sebagai Ekstraksi Ciri dan Backpropagation sebagai Classifier
}

\section{Lung Sound Recognition using MFCC as A Feature Extraction and Backpropagation as A Classifier}

\author{
FADHILAH SYAFRIA ${ }^{1}$, AGUS BUONO ${ }^{1 *}$, BIB PARUHUM SILALAHI $^{2}$
}

\begin{abstract}
Abstrak
Paru-paru merupakan organ vital manusia yang berperan dalam proses pernapasan. Jika paru-paru mengalami gangguan maka sistem pernapasan manusia juga akan mengalami gangguan yang bisa menyebabkan kecacatan bahkan kematian. Untuk mengevaluasi keadaan paru-paru dapat dilakukan dengan mendengarkan suara pernapasan dengan menggunakan stateskop. Teknik ini dikenal dengan teknik auskultasi. Teknik ini paling sering digunakan namun memiliki beberapa kelemahan yaitu suara paru-paru berada pada frekuensu rendah, masalah kebisingan lingkungan, kepekaan telinga, hasil analisa yang subjektif, dan pola suara yang hampir mirip. Karena faktor-faktor di atas kesalahan diagnosa bisa terjadi jika proses auskultasi tidak dilakukan dengan benar. Dalam penelitian ini, akan dibuat pengenalan suara paru-paru normal dan abnormal menggunakan $\mathrm{Mel}$ Frequency Cepstrum koefisien (MFCC) sebagai ekstraksi ciri dan Backpropagation sebagai classifier. Suara paru-paru akan dihitung Coeffisient Ceptral nya sebagai penciri dari masing-masing suara untuk selanjutnya dikenali dengan menggunakan Backpropagation. Metode yang diusulkan memberikan akurasi $93.97 \%$ untuk data latih dan $92.66 \%$ untuk data uji.
\end{abstract}

Kata kunci: Backpropagation, MFCC, pengenalan suara paru-paru

\begin{abstract}
The lungs are vital organs of humans who play a role in the process of breathing. If the lung having disorder then the human respiratory system will also experience interference that can lead to disability and even death. To evaluate the state of the lungs can be done by listening to the sound of breathing by using stateskop. This technique is known as auscultation. This technique is most commonly used but has some drawbacks, namely the lung sounds have low frequency, low amplitude, in addition to other factors such as interference from other sounds, ear sensitiveness, subjectivity of physician diagnosis and sound patterns almost similar between lung sounds with each other. These problems can lead to the false diagnosing if the auscultation procedures are not conducted correctly. In this study, speech recognition will be made of normal lung and abnormal lung use Mel Frequency Cepstrum Coeffisient (MFCC) as feature extraction and Backpropagation as the classifier. The lung sounds will be calculated of its Ceptral Coeffisient as feature of each sounds to be recognized by using Backpropagation next. The proposed method gives an accuracy of $93.97 \%$ for training data and $92.66 \%$ for test data.
\end{abstract}

Keywords: backpropagation, lung sound recognition, MFCC

\section{PENDAHULUAN}

Paru-paru merupakan salah satu organ vital manusia. Organ ini memiliki peranan pada sistem pernapasan, karena dapat memenuhi kebutuhan tubuh akan oksigen.

\footnotetext{
${ }^{1}$ Departemen Ilmu Komputer, Fakultas Matematika dan Ilmu Pengetahuan Alam, Institut Pertanian Bogor, Bogor 16680

${ }^{2}$ Departemen Matematika, Fakultas Matematika dan Ilmu Pengetahuan Alam, Institut Pertanian Bogor, Bogor 16680

*Penulis korespondensi: Tel/Faks: 0251-8625584; Surel: pudesha@yahoo.co.id
} 
Jika paru-paru mengalami gangguan, maka sistem pernapasan manusia juga akan mengalami gangguan, bahkan dapat menyebabkan kematian.

Paru-paru merupakan organ tubuh manusia yang sangat penting, karena jika paru-paru mengalami gangguan/kerusakan maka bisa menyebabkan kematian bagi penderitanya. Diperkirakan ratusan ribu sampai jutaan penduduk dunia terkena penyakit paru setiap tahun dan hal tersebut menyebabkan $19 \%$ penyebab kematian diseluruh dunia dan $15 \%$ penyebab kecacatan sepanjang hidup (FIRS 2010). Menurut proyeksi WHO, pada tahun 2020 penyakit paru-paru termasuk 10 penyebab masalah kesehatan masyarakat di dunia (WHO 2008). Sedangkan di indonesia penyakit paru-paru menduduki 10 besar peringkat utama untuk penyebab masalah kesehatan masyarakat (PDPI 2010). Perlunya meningkatkan kepedulian mengenai penyakit paru adalah hal yang vital karena penyakit paru membunuh lebih banyak orang setiap tahunnya dan sesuatu harus dilakukan untuk hal tersebut.

Salah satu cara yang digunakan dokter untuk mendiagnosa gangguan pada paru-paru adalah dengan mendengarkan suara pernapasan menggunakan stetoskop. Perangkat ini ditemukan pada tahun 1821 oleh seorang dokter prancis bernama Laennec (Sovijarvi et al. 2000). Suara pernapasan memiliki informasi penting untuk mengetahui kelainan yang ada pada paru-paru (Emmanouilidou at al. 2012).

Teknik mendengarkan suara nafas menggunakan stetoskop dikenal dengan teknik auskultasi. Teknik auskultasi merupakan teknik dasar yang digunakan oleh dokter untuk mengevaluasi suara nafas. Teknik ini cukup sederhana dan murah, namun memiliki kelemahan yaitu hasil analisisnya yang subjektif (Kiyokawa et al. 2013). Hasil analisis suara nafas menggunakan teknik auskultasi bergantung pada kemampuan, pengalaman dan pendengaran dokter yang melakukan analisis. Selain itu, pendengaran manusia yang kurang sensitif terhadap suara dengan frekuensi yang rendah juga menjadi permasalahan dalam teknik ini, dimana suara paru-paru berada pada frekuensi rendah. Masalah lainnya dalam teknik auskultasi adalah masalah kebisingan lingkungan dan pola suara yang hampir mirip antara jenis suara nafas satu dan yang lain. Karena faktor-faktor tersebut, kesalahan diagnosis bisa terjadi apabila prosedur auskultasi tidak dilakukan dengan benar.

Berdasarkan permasalahan di atas, peneliti tertarik untuk melakukan penelitian dalam melakukan pengenalan suara paru-paru normal dan suara paru-paru yang terdeteksi gangguan (abnormal). Suara paru-paru yang dihasilkan pada beberapa kasus penyakit menunjukkan adanya pola tertentu yang bisa dikenali. Pola suara ini dapat diambil sebagai bahan untuk diagnosa (Rizal et al. 2010). Suara paru-paru akan diklasifikasi menjadi empat kelas yaitu suara tracheal, suara vesicular, suara crackle dan suara wheeze. Suara tracheal dan suara vesicular mengindikasikan paru-paru nomal, sedangkan suara crackle dan suara wheeze mengindikasikan kelainan pada paru-paru (Abaza et al. 2009; Gurung et al. 2011).

Pengenalan suara secara umum memiliki dua bagian utama, yaitu ekstrasi ciri dan pengukuran kemiripan (klasifikasi). Pada penelitian ini, metode ekstraksi ciri yang digunakan adalah Mel Frequency Coeffisient Cepstrum (MFCC). MFCC memberikan hasil sangat baik dalam mengklasifikasi suara nafas normal dan suara wheeze (Bahoura 2009). Untuk metode klasifikasi yang digunakan adalah metode backpropagation. Algoritma backpropagation adalah algoritma pembelajaran yang populer untuk memecahkan kasus-kasus yang rumit. Algoritma ini melakukan dua tahap perhitungan, yaitu: perhitungan maju untuk menghitung error antara keluaran actual dan target. Dan perhitungan mundur yang mempropagasikan balik error tersebut untuk memperbaiki bobot-bobot pada semua neuron yang ada. Penggunaan kedua metode di atas diharapkan dapat memberikan akurasi yang tinggi dalam kasus pengenalan suara paru-paru. 


\section{METODE}

Metode penelitian ini diilustrasikan pada Gambar 1. Pada gambar tersebut terlihat penelitian dimulai dengan kajian pustaka tentang teori-teori yang diperlukan untuk penyelesaian penelitian ini, seperti teori suara paru-paru, MFCC dan backpropagation.

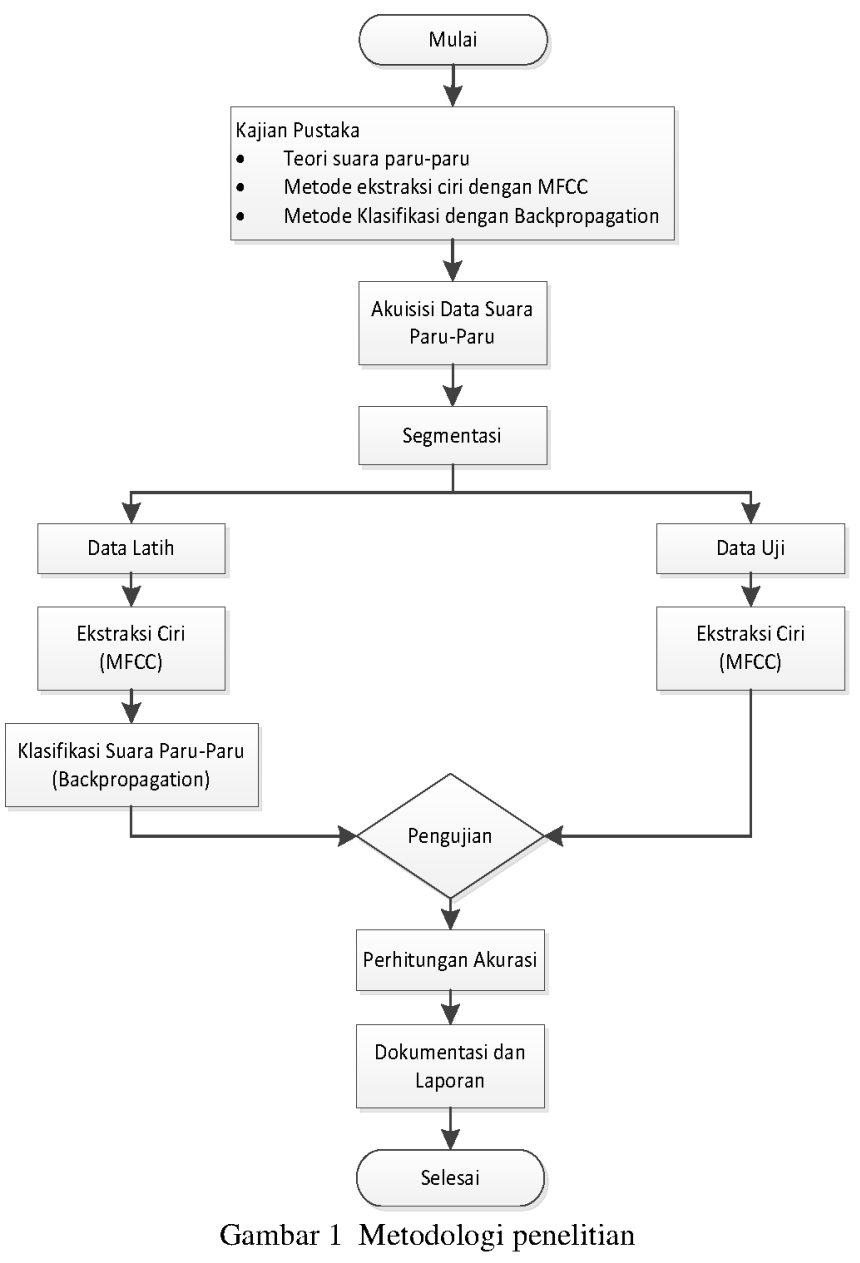

\section{Data Suara (Bahan Penelitian)}

Data suara paru-paru diperoleh dari repository suara pernapasan yang ada di internet yaitu Littmann Repository. Data suara tersebut terdiri dari 32 data suara paru-paru, yang terbagi menjadi 8 suara tracheal, 8 suara vesicular, 8 suara crackle dan 8 suara wheeze. Data direkam dengan frekuensi sampling $44100 \mathrm{~Hz}$, stereo dalam format*.wav.

Suara pernafasan tracheal merupakan suara yang terdengar pada bagian laring dan pangkal leher. Suara tracheal sangat nyaring dan pitch-nya tinggi (Gambar 2a), sehingga suara ini sangat jelas terdengar dibandingkan suara paru-paru normal lainnya. Inspirasi dan ekspirasi relatif sama panjang (Rizal et al. 2006).

Suara pernafasan vesicular merupakan suara pernafasan normal yang didengar pada dada samping dan dada dekat perut. Suaranya lembut dengan pitch rendah (Gambar 2b). Suara inspirasi jauh lebih kuat dibanding suara ekspirasi. Sering kali proses ekspirasi hampir tidak terdengar.

Crackles merupakan suara ledakan pendek yang bersifat discontinuous (Gambar 2c), suara ini umumnya lebih terdengar pada proses inspirasi (Katila et al. 1991). Pada suara crackles ini jika didengarkan akan terdengar suara putus-putus. Kondisi penyebab terjadinya crackles yaitu ARDS, asthma, bronchiectasis, chronic bronchitis, consolidation, early CHF, nterstitial lung disease dan pulmonary edema (Ramadhan 2012). 

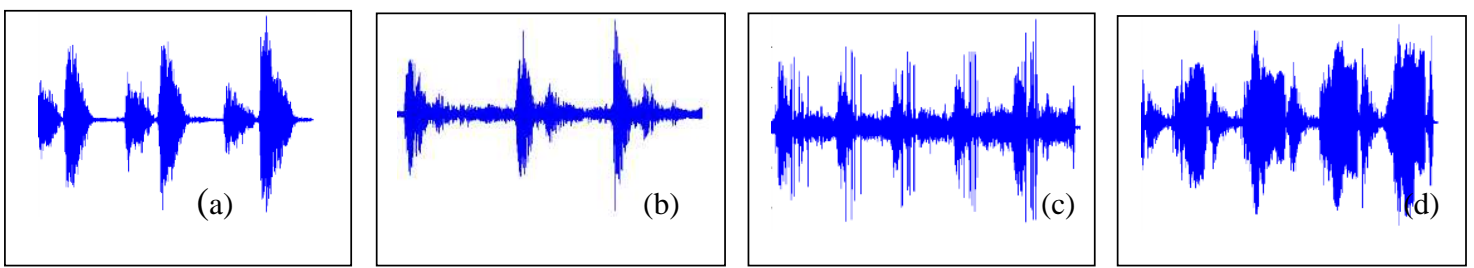

Gambar 2 Jenis Suara Paru-Paru. (a) Tracheal (b) Vesicular (c) Crackle (d) Wheeze

Wheezes merupakan jenis suara yang bersifat kontinyu, memiliki pitch tinggi (Gambar 2d), dan lebih sering terdengar pada proses ekspirasi. Suara ini terjadi saat aliran udara melalui saluran udara yang menyempit karena sekresi, benda asing atau luka yang menghalangi (Rizal et al. 2010). Kondisi yang menyebabkan suara wheeze yaitu asthma, CHF, chronic bronchitis, COPD dan pulmonary edema (Ramadhan 2012).

\section{Segmentasi Suara}

Data sampel suara paru-paru yang telah diperoleh dari tahap akuisis data akan disegmentasi berdasarkan satu siklus pernapasan yaitu fase inspirasi dan fase ekspirasi. Proses segmentasi sinyal suara dilakukan dengan menggunakan software Audacity. Segmentasi sinyal menghasilkan daftar suara paru-paru yang telah terpotong sesuai dengan satu siklus pernapasan. Proses segmentasi menghasilkan 96 data suara paru-paru yang masing-masing jumlahnya tercantum pada Tabel 1.

Tabel 1 Jumlah Suara Hasil Segmentasi

\begin{tabular}{ccc}
\hline No & Jenis Suara Paru & Jumlah \\
\hline 1 & Tracheal & 24 Suara \\
2 & Vesicular & 24 Suara \\
3 & Crackles & 24 Suara \\
4 & Wheeze & 24 Suara \\
& Total & 96 Suara \\
\hline
\end{tabular}

\section{Pembagian Data Latih dan Data Uji}

Data suara paru-paru yang telah disegmentasi dibagi menjadi dua bagian, yaitu data latih dan data uji. Jumlah data suara paru-paru hasil proses segmentasi yaitu 96 data suara. Data suara paru-paru tersebut kemudian ditetapkan 80 suara sebagai data latih dan 16 suara sebagai data uji.

\section{Ekstraksi Ciri MFCC}

Ekstraksi ciri MFCC merupakan suatu teknik yang digunakan untuk menghasilkan suatu vektor yang digunakan sebagai penciri (Patel dan Prasad 2013). Ciri tersebut adalah koefisien cepstral, koefisien cepstral yang digunakan tetap mempertimbangkan persepsi sistem pendengaran manusia. Teknik MFCC dapat merepresentasikan sinyal lebih baik dibandingkan LPC, LPCC dan yang lainnya dalam pengenalan suara (Buono 2009). Hal ini dikarenakan cara kerja MFCC didasarkan pada perbedaan frekuensi yang dapat ditangkap oleh telinga manusia sehingga bisa merepresentasikan bagaimana manusia menerima sinyal suara (Muda et al. 2010). Gambar 3 merupakan diagram alur MFCC. 

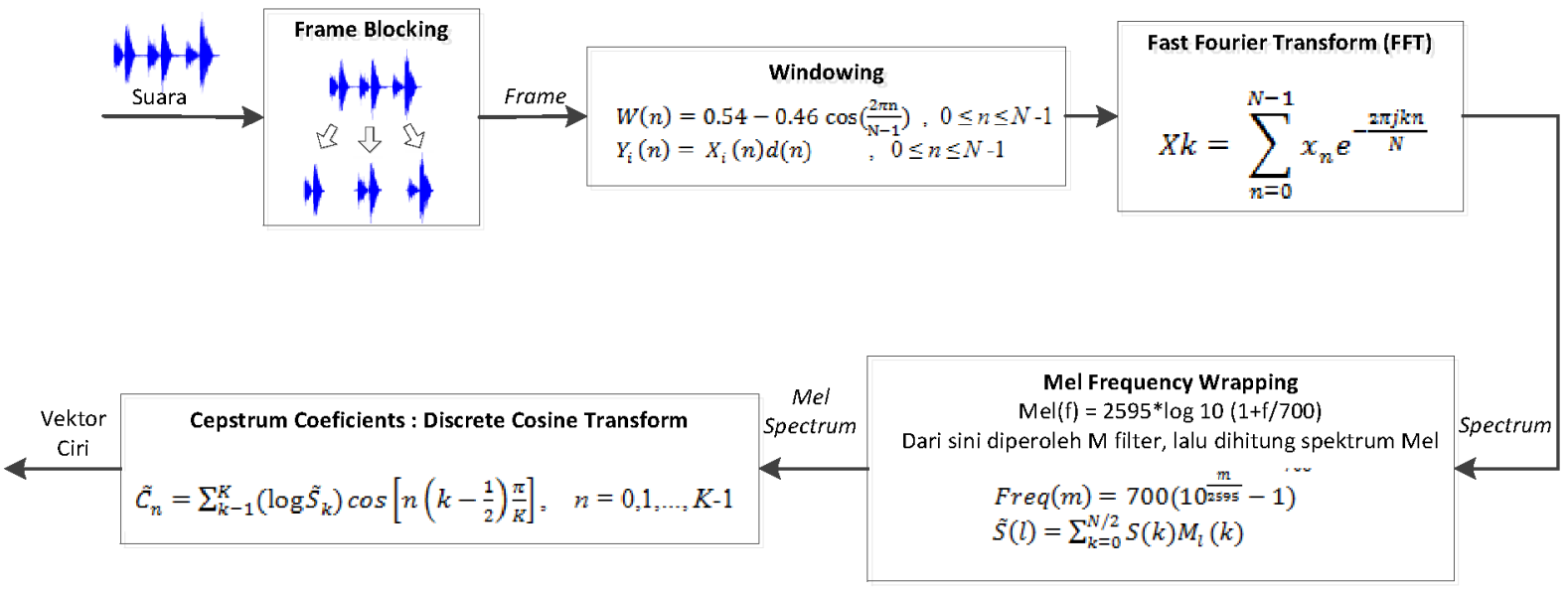

Gambar 3 Diagram alur MFCC

\section{Klasifikasi Suara Paru-Paru (Backpropagation)}

Data suara paru yang telah diperoleh vektor pencirinya melalui proses ekstraksi ciri akan diklasifikasikan menggunakan metode bacpropagation. Hasil pemrosesan awal berupa data sampel suara yang telah disegmentasi dan dilakukan proses ektraksi ciri akan menjadi input dari metode backpropagation.

Backpropagation merupakan sebuah metode sistematik pada jaringan saraf tiruan dengan menggunakan algoritma pembelajaran yang terawasi (supervised) dan biasanya digunakan oleh perceptron dengan banyak lapisan (lapisan input, lapisan tersembunyi dan lapisan output) untuk mengubah bobot-bobot yang ada pada lapisan tersembunyinya (Suhandi 2009). Backpropagation adalah pelatihan jenis terkontrol dimana menggunakan pola penyesuaian bobot untuk mencapai nilai kesalahan yang minimum antara keluaran hasil prediksi dengan keluaran yang nyata. Untuk mendapatkan error jaringan ini, fase perambatan maju (feedforward) harus dilakukan sebelumnya.

Pada fase feedforward, tiap-tiap unit input menerima sinyal dan meneruskan sinyal tersebut ke semua unit pada lapisan yang ada di atasnya (lapisan tersembunyi). Tiap-tiap unit pada suatu lapisan tersembunyi menjumlahkan sinyal-sinyal input yang diterimanya. Pada langkah ini digunakan fungsi aktivasi untuk menghitung sinyal output yang akan dikirim ke semua unit di atasnya (lapisan output). Langkah ini dilakukan sebanyak jumlah lapisan tersembunyi. Kemudian tiap-tiap unit output menjumlahkan sinyal-sinyal output. Pada langkah ini juga digunakan fungsi aktivasi untuk menghitung sinyal output-nya.

Setelah fase feedforward, langkah selanjutnya adalah fase backforward. Pada fase ini, tiap-tiap unit output menerima target pola yang berhubungan dengan pola input pembelajaran lalu hitung informasi error-nya. Kemudian hitung koreksi bobot dan koreksi biasnya. Langkah ini dilakukan sebanyak jumlah lapisan tersembunyi. Tiap-tiap unit tersembunyi menjumlahkan delta inputnya (dari unit-unit yang berada pada lapisan di atasnya). Kalikan nilai delta dengan turunan fungsi aktivasinya untung menghitung informasi error, lalu hitung koreksi bobot dan koreksi biasnya. Langkah terakhir, tiap-tiap unit output memperbaiki bobot dan biasnya, begitu juga dengan unit tersembunyi yang juga memperbaiki bobot dan biasnya.

\section{Perhitungan Akurasi}

Setelah tahap pengujian, dilakukan perhitungan nilai akurasi dari penelitian untuk mengetahui tingkat akurasi dari pengenalan suara paru-paru serta untuk mengukur pengaruh beberapa parameter terhadap akurasi pengenalan suara paru-paru. Tingkat akurasi pengenalan suara paru-paru dihitung dengan Persamaan 1 berikut :

$$
\text { Akurasi }=\frac{\text { Jumlah suara yang benar }}{\text { Jumlah suara yang diuji }} \times 100 \%
$$




\section{HASIL DAN PEMBAHASAN}

\section{Hasil Pra-Proses}

Hasil akhir dari tahap segmentasi sinyal adalah 96 data suara paru-paru yang telah terpotong-potong berdasarkan satu siklus pernapasan yaitu fase inspirasi dan fase ekspirasi. Data hasil segmentasi ini akan dibagi ke dalam dua kelompok data yaitu kelompok data pelatihan (training set) dan kelompok data pengujian (testing set). Pembagian ke dalam kelompok-kelompok data tersebut adalah untuk mengetahui data mana saja yang akan dijadikan data pelatihan pada pembentukan model jaringan syaraf tiruan LVQ dan FLVQ dan data mana saja yang akan dijadikan data pengujian.

Dari 96 data suara hasil segmentasi suara akan diambil 80 data suara sebagai data latih dan 16 data sisanya sebagai data uji. Komposisi pembagian data latih dan data uji dapat dilihat pada Tabel 2. Dari tabel tersebut dapat dilihat bahwa total percobaan yang dilakukan adalah sebanyak 21 percobaan.

Tabel 2 Kelompok Data Latih dan Data Uji

\begin{tabular}{lll}
\hline No & \multicolumn{1}{c}{ Kelompok Data Latih } & \multicolumn{1}{c}{$\begin{array}{c}\text { Kelompok Data } \\
\text { Uji }\end{array}$} \\
\hline 1 & $5,6,7,8,9,10,11,12,13,14,15,16,17,18,19,20,21,22,23,24$ & $1,2,3,4$ \\
2 & $1,6,7,8,9,10,11,12,13,14,15,16,17,18,19,20,21,22,23,24$ & $2,3,4,5$ \\
3 & $1,2,7,8,9,10,11,12,13,14,15,16,17,18,19,20,21,22,23,24$ & $3,4,5,6$ \\
4 & $1,2,3,8,9,10,11,12,13,14,15,16,17,18,19,20,21,22,23,24$ & $4,5,6,7$ \\
5 & $1,2,3,4,9,10,11,12,13,14,15,16,17,18,19,20,21,22,23,24$ & $5,6,7,8$ \\
6 & $1,2,3,4,5,10,11,12,13,14,15,16,17,18,19,20,21,22,23,24$ & $6,7,8,9$ \\
7 & $1,2,3,4,5,6,11,12,13,14,15,16,17,18,19,20,21,22,23,24$ & $7,8,9,10$ \\
8 & $1,2,3,4,5,6,7,12,13,14,15,16,17,18,19,20,21,22,23,24$ & $8,9,10,11$ \\
9 & $1,2,3,4,5,6,7,8,13,14,15,16,17,18,19,20,21,22,23,24$ & $9,10,11,12$ \\
10 & $1,2,3,4,5,6,7,8,9,14,15,16,17,18,19,20,21,22,23,24$ & $10,11,12,13$ \\
11 & $1,2,3,4,5,6,7,8,9,10,15,16,17,18,19,20,21,22,23,24$ & $11,12,13,14$ \\
12 & $1,2,3,4,5,6,7,8,9,10,11,16,17,18,19,20,21,22,23,24$ & $12,13,14,15$ \\
13 & $1,2,3,4,5,6,7,8,9,10,11,12,17,18,19,20,21,22,23,24$ & $13,14,15,16$ \\
14 & $1,2,3,4,5,6,7,8,9,10,11,12,13,18,19,20,21,22,23,24$ & $14,15,16,17$ \\
15 & $1,2,3,4,5,6,7,8,9,10,11,12,13,14,19,20,21,22,23,24$ & $15,16,17,18$ \\
16 & $1,2,3,4,5,6,7,8,9,10,11,12,13,14,15,20,21,22,23,24$ & $16,17,18,19$ \\
17 & $1,2,3,4,5,6,7,8,9,10,11,12,13,14,15,16,21,22,23,24$ & $17,18,19,20$ \\
18 & $1,2,3,4,5,6,7,8,9,10,11,12,13,14,15,16,17,22,23,24$ & $18,19,20,21$ \\
19 & $1,2,3,4,5,6,7,8,9,10,11,12,13,14,15,16,17,18,23,24$ & $19,20,21,22$ \\
20 & $1,2,3,4,5,6,7,8,9,10,11,12,13,14,15,16,17,18,19,24$ & $20,21,22,23$ \\
21 & $1,2,3,4,5,6,7,8,9,10,11,12,13,14,15,16,17,18,19,20$ & $21,22,23,24$ \\
\hline
\end{tabular}

Dengan pembagian data latih dan data uji dengan cara di atas, dapat dilihat bahwa semua data diperlakukan secara adil dan berkesempatan menjadi data latih dan data uji.

\section{Hasil Ekstraksi Ciri}

Proses ekstraksi ciri bertujuan untuk mendapatkan vektor penciri suatu objek. Prinsip dasarnya adalah mereduksi ukuran data, namun tidak menghilangkan informasi penting yang menjadi penciri suatu objek. Ilustrasi perubahan data asli menjadi data hasil MFCC dapat dilihat pada Gambar 4. Hasil akhir proses ekstraksi ciri adalah arsip yang berisi data ciri suara. Pada penelitian ini, akan digunakan empat koefisien MFCC yaitu 13, 15, 20 dan 30. Sehingga akan dihasilkan vektor penciri yang berukuran 13x96, 15x96, 20x96 dan 30x96. Gambar 25 berikut adalah ilustrasi perubahan data asli menjadi data hasil MFCC. 


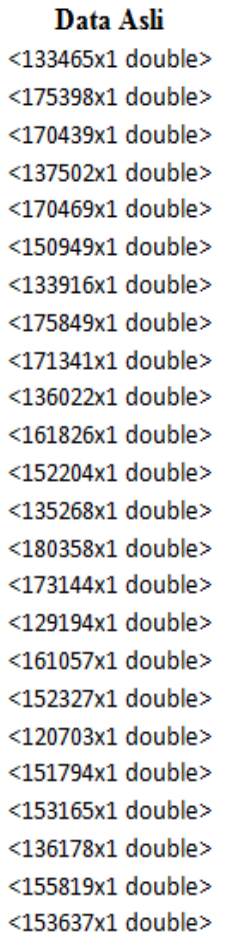

\author{
Data Hasil MFCC \\ <13x1 double> \\ $<13 \times 1$ double $>$ \\ $<13 \times 1$ double> \\ $<13 \times 1$ double> \\ $<13 \times 1$ double> \\ $<13 \times 1$ double $>$ \\ $<13 \times 1$ double $>$ \\ $<13 \times 1$ double $>$ \\ $<13 \times 1$ double> \\ $<13 \times 1$ double $>$ \\ $<13 \times 1$ double> \\ $<13 \times 1$ double> \\ $<13 \times 1$ double> \\ $<13 \times 1$ double $>$ \\ $<13 \times 1$ double $>$ \\ $<13 \times 1$ double $>$ \\ $<13 \times 1$ double $>$ \\ $<13 \times 1$ double $>$ \\ $<13 \times 1$ double> \\ <13x1 double> \\ $<13 \times 1$ double> \\ $<13 \times 1$ double> \\ $<13 \times 1$ double $>$ \\ $<13 \times 1$ double>
}

Gambar 4 Ilustrasi Perubahan Data Asli Menjadi hasil MFCC (Data Suara Tracheal Untuk Koefisien MFCC 13)

\section{Hasil Pengujian Metode Backpropagation}

Pada bagian ini akan dibahas mengenai hasil penelitian serta akurasi yang dihasilkan oleh metode bakcpropagation pada pengenalan suara paru-paru. Pengujian dilakukan dengan merubah-rubah jumlah koefisien MFCC dan learning rate untuk melihat pengaruhnya terhadap tingkat akurasi pengenalan. Untuk koefisien MFCC yang digunakan adalah 13, 15, 20 dan 30. Sedangkan untuk nilai learning rate yang digunakan adalah $0.1,0.2,0.3,0.4$ dan 0.5 . Sehingga terdapat 20 kombinasi parameter. Tabel 2 berikut menunjukkan struktur JST backpropagation yang digunakan dalam penelitian :

Tabel 3 Struktur JST Backpropagation

\begin{tabular}{|c|c|}
\hline Karakteristik & Spesifikasi \\
\hline Arsitektur & $\begin{array}{c}\text { Neuron lapis masukan, Neuron lapis tersembunyi dan neuron lapis } \\
\text { keluaran }\end{array}$ \\
\hline Neuron lapis masukan & $\begin{array}{l}\text { 13, 15, } 20 \text { dan } 30 \text { (sesuai jumlah koefisien MFCC yang dihasilkan pada } \\
\text { proses ekstraksi ciri }\end{array}$ \\
\hline Neuron lapis tersembunyi & 10 \\
\hline Neuron lapis keluaran & 4 (sebanyak jenis kelas/jenis suara paru-paru) \\
\hline Toleransi galat & 0.001 \\
\hline Fungsi aktivasi & Sigmoid dan Linier \\
\hline Jumlah iterasi & 200 \\
\hline Pembelajaran & Gradient Descent \\
\hline Laju pembelajaran & $0.1 ; 0.2 ; 0.3 ; 0.4$ dan 0.5 \\
\hline
\end{tabular}

Dari hasil pengujian pada backpropagation dengan mengubah-ubah nilai parameter koefisien MFCC dan learning rate, didapatkan tingkat akurasi yang berbeda-beda pada pengujian dengan data latih dan data uji seperti yang disajikan pada Tabel 3 dan Tabel 4 . Pada Tabel 3 dapat dilihat bahwa nilai akurasi tertinggi terjadi pada kombinasi parameter koefisien MFCC 13 dan learning rate 0.5 dengan akurasi pengenalan 98.21\% (ditandai cetak tebal). Sama halnya dengan nilai akurasi tertinggi untuk data uji (Tabel 4) terjadi pada kombinasi parameter koefisien MFCC 13 dan learning rate 0.4 dengan akurasi pengenalan 
97.92\% (ditandai cetak tebal). Namun secara keseluruhan rata-rata akurasi yang didapatkan pada metode ini adalah sebesar $93.97 \%$ untuk data latih dan $92.66 \%$ untuk data uji. Pengujian dengan data latih memberikan hasil akurasi yang lebih baik karena data tersebut juga digunakan dalam proses pelatihan, sedangkan data uji tidak diikutsertakan pada saat pelatihan.

Tabel 3 Akurasi Pengujian pada Backpropagation

\begin{tabular}{cccccc}
\hline $\begin{array}{c}\text { Koefisien } \\
\text { MFCC }\end{array}$ & 0.1 & 0.2 & 0.3 & 0.4 & $\mathbf{0 . 5}$ \\
\hline $\mathbf{1 3}$ & 90.18 & 95.12 & 95.95 & 98.04 & $\mathbf{9 8 . 2 1}$ \\
15 & 91.55 & 94.29 & 96.96 & 97.08 & 96.67 \\
20 & 89.35 & 94.23 & 94.76 & 94.82 & 95.30 \\
30 & 83.57 & 89.23 & 92.74 & 95.48 & 95.95 \\
\hline
\end{tabular}

Tabel 4 Akurasi Pengujian pada Backpropagation

\begin{tabular}{cccccc}
\hline $\begin{array}{c}\text { Koefisien } \\
\text { MFCC }\end{array}$ & 0.1 & 0.2 & 0.3 & $\mathbf{0 . 4}$ & 0.5 \\
\hline $\mathbf{1 3}$ & 90.48 & 93.15 & 94.35 & $\mathbf{9 7 . 9 2}$ & 96.43 \\
15 & 90.48 & 92.86 & 95.83 & 95.83 & 95.54 \\
20 & 88.10 & 91.96 & 91.96 & 94.35 & 94.64 \\
30 & 83.63 & 86.90 & 90.18 & 93.45 & 95.24 \\
\hline
\end{tabular}

\section{Pengaruh Jumlah Koefisien MFCC Terhadap Akurasi}

Dari seluruh percobaan, didapatkan rata-rata akurasi pada setiap nilai koefisien MFCC yang ditampilkan pada Gambar 4. Dari grafik tersebut dapat dilihat bahwa pada metode backpropagation akurasi tertinggi terjadi ketika menggunakan koefisien MFCC 13 baik untuk data latih maupun data uji, yaitu $95.50 \%$ untuk data latih dan $94.46 \%$ untuk data uji. Secara keseluruhan, terdapat kecenderungan bahwa semakin tinggi nilai koefisien MFCC justru membuat akurasi lebih rendah, meskipun penurunannya tidak terlalu signifikan. Penurunan akurasi dengan penambahan jumlah koefisien MFCC disebabkan semakin tinggi koefisien MFCC berdampak pada dimensi data yang lebih besar. Dimensi data yang besar membuat kemampuan generalisasi JST lebih rendah sehingga akurasinya pun menurun.

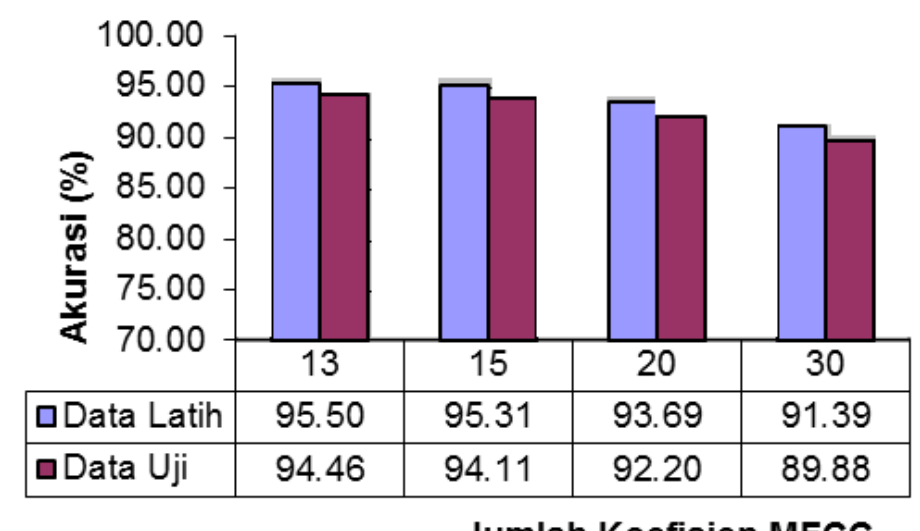

Gambar 4 Grafik Akurasi perbandingan berdasarkan koefisien MFCC

\section{Pengaruh Learning Rate Terhadap Akurasi}

Pengaruh learning rate pada seluruh percobaan terhadap rata-rata akurasi ditampilkan pada Gambar 5. Dari grafik tersebut dapat dilihat bahwa pada metode backpropagation 
akurasi tertinggi terjadi ketika menggunakan learning rate 0.5 baik untuk data latih maupun data uji, yaitu $96.53 \%$ untuk data latih dan $95.46 \%$ untuk data uji. Secara keseluruhan terdapat kecendrungan bahwa akurasi cenderung meningkat seiring meningkatnya learning rate dengan peningkatan yang fluktuatif. Hal ini disebabkan algoritme backpropagation hanya mengubah bobot jaringan dengan menjumlahkan (tanpa sifat kompetisi) sehingga bobot jaringan tetap stabil. Namun pada beberapa kasus, nilai learning rate yang terlalu tinggi dapat membuat akurasi lebih rendah.

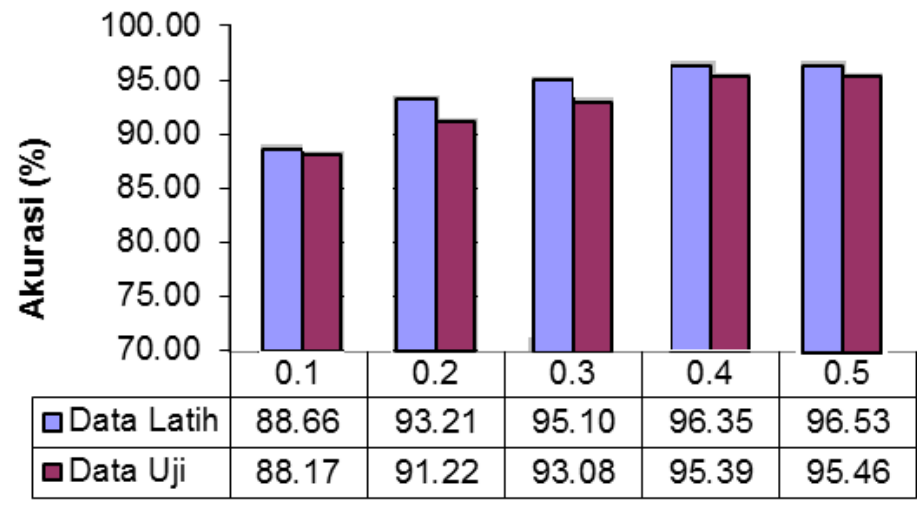

Learning Rate

Gambar 5 Grafik Akurasi Berdasarkan Learning Rate

\section{SIMPULAN}

Dari hasil penelitian yang telah dilakukan, dapat disimpulkan bahwa telah dibuat suatu model pengenalan suara paru-paru dengan ekstraksi ciri MFCC. Klasifikasi dengan metode backpropagation dapat diterapkan untuk identifikasi suara paru-paru, dengan mengatur parameter koefisien MFCC dan learning rate yang memaksimumkan tingkat akurasi. Metode Backpropagation memberikan akurasi yang cukup tinggi yaitu sebesar $93.97 \%$ untuk data latih dan $92.66 \%$ untuk data uji.

\section{DAFTAR PUSTAKA}

Abaza AA, Day JB, Reynolds JS, Mahmoud AM, Goldsmith WT, McKinney WG, Petsonk EL, Frazer DG. 2009. Classification of voluntary cough sound and airflow patterns for detecting abnormal pulmonary function. Cough. 5(8)

Bahoura M. 2009. Pattern Recognition Methods Applied to Respiratory Sounds Classification into Normal and Wheeze Classes. Computers and Biology and Medicine. 39(9):824843.

Buono A. 2009. Representasi nilai hos dan model MFCC sebagai ekstraksi ciri pada sistem indentifikasi pembicara di lingkungan ber-noisemenggunakan HMM [disertasi]. Depok: Program Studi Ilmu Komputer, Universitas Indonesia.

Emmanouilidou D, Patil K, West J, Elhilali M. 2012. A Multiresolution Analysis for Detection of Abnormal Lung Sounds. IEEE EMBS. 3139-3142

Forum of International Respiratory Societies (FIRS). 2010. The Year of The Lung. Available from : http://www.2010yearofthelung

Gurung A, Scrafford CG, Tielsch JM, Levine OS, Checkley W. 2011. Computerized lung sound analysis as diagnostic aid for the detection of abnormal lung sounds: a systematic review and meta-analysis. Respir Med. 105(9): 1396-1403 
Kiyokawa H, Greenberg MDM, Shirota K, Pasterkamp H. 2013. Auditory Detection of Simulated Crackels in Breath Sounds. CHEST. 119(6): 1886-1892

Muda L, Begam M, Elamvazuthi I. (2010). Voice Recognition Algorithms Using Mel Frequency Cepstral Coefficient (MFCC) and Dynamic Time Warping (DTW) Techniques. Journal of Computing, Volume 2, Issue 3.

Patel K, Prasad RK. 2013. Speech Recognition and Verification Using MFCC \& VQ. Interntional Journal.

Perhimpunan Dokter Paru Indonesia. Press Release : Year of the Lung 2010. Jakarta, 21 Januari 2010.

Ramadhan MZ. 2012. Perancangan Sistem Instrumentasi untuk Identifikasi dan Analisis Suara Paru-Paru Menggunakan DSP TMS320C6416T [Skripsi]. Depok[ID]: Universitas Indonesia

Rizal A, Anggraeni L, Suryani V. 2006. Pengenalan Suara Paru-Paru Normal Menggunakan LPC dan Jaringan Syaraf Tiruan Back-Propagation. Proceeding EECCIS2006, Mei.

Rizal A, Samudra MD, Iwut I, Suryani V. 2010. Pengenalan Suara Paru Menggunakan Spektogram dan K-Mean Clustering. Proceeding SITIA2010, Februari

Sovijarvi ARA, Vanderschoot J, Earis JE. 2000. Standardization of Computerized Respiratory Sound Analysis. European Respiratory Review. 10(77): 585

Suhandi Krisna, 2009, Prediksi Harga Saham dengan Pendekatan Artificial Neural Network menggunakan Algoritma Backpropagation

World Health Organization. World Health Statistics 2008. France : WHO 2008. 